\title{
Conservation and Geometry, Very Old Marriage for Iranian Historical Building
}

\author{
Hanieh Mohammadi* \\ Restoration and Conservation faculty, Art University of Isfahan, Iran \\ *Corresponding author: Hanieh Mohammadi, Restoration and Conservation faculty, Art University of Isfahan, Isfahan, Iran \\ Submission: 眥August 17,2017; Published: 眥 November 13, 2017
}

\begin{abstract}
Iranian Architecture, depending on materials and various factors have various forms, the geometric proportions is one of the factors affecting the form of building in both Structure and decoration. Geometrical shapes in nature have always inspired Iranian architect. As Architecture is closely tied with geometry, orders and proportions over thousands of years, analyzing shapes and finding geometric ratios used in historical monuments and sites can be used in damaged constructions, which need to rebuild or repair. Therefore, this research tries to discover geometry rules in nature and then reveals that architecture is closely related to geometry, too. This Effort has been made by library studies on the one hand and on the other hand is based on field data to achieve geometrical qualities in different periods of Iran. Analyses done by the author revealed that discovery the geometry rules in historical buildings is the first step to rebuild the loosing parts.
\end{abstract}

Keywords: Geometry; Conservation; Historical building; Iranian architecture

\section{Introduction}

In the universal and lawful world of geometry, everything has its own size and quality and this makes them unique. By means of geometry, every object finds its limits and size, get in touch with the environment, and finds its path towards the completion without any interruption [1].

Research in Iranian architecture without knowledge of the geometry is impossible. Throughout history, people considered geometry as an important science, balanced with mathematics, astrology and music. In Iranian architecture, geometrical and abstract patterns were emphasized as a best forming factor (of whole structure) and decoration method (of components). Geometry has a fundamental role in designing of Iranian building. As far as outside is concerned, geometry is an art to create shapes, patterns, and proportions, which reminds us God Creations. Geometry is a key element to link the building with architect's intellect. In regard to inside, a science helps to choose the proper size, length, width and height of materials in the construction.

Unfortunately, nowadays many parts of historical structures have been lost without any authentic documents to rebuild and reconstruct them. A geometric approach leads to a functional solution to find these destroyed parts. It seems that studying and consideration of geometry qualities in historical building could have a valuable influence on conservation developing. Although, Geometric analysis of ancient architecture has only been able to reveal some of the forgotten mysteries of the past techniques used, it can demonstrate the mastery of Architectural skills [2].
So, the key question in present investigation is as follows:

1. Which part of your environment has revealed geometrical rules and repetitive proportions?

2. How the Geometry has been used in different period of traditional Iranian architecture?

3. How is it possible to achieve a correct conservation for loosing part of historical building?

This study was carried out based on library and field studies to answer above questions.

\section{Geometry in Various Field}

Vitruvius believed that builders should always use precise ratios when constructing temples. "For without symmetry and proportion no temple can have a regular plan," Vitruvius wrote.

The symmetry and proportion Vitruvius recommended was modeled after the human body. Vitruvius observed that all human are shaped according to a ratio that is astonishingly precise and uniform. For example, Vitruvius found that the human face equals one tenth of the total body height. The foot equals one sixth of the total body height. And so on.

Scientists and philosophers later discovered that the same ratio Vitruvius saw in the human body exists in every part of nature, from swimming fish to swirling planets. Sometimes called a golden ratio, divine ratio or even sacred geometry. 
Following significant proportion and geometry, is the belief that numbers and patterns such as the divine ratio have sacred significance. Many mystical and spiritual practices, including astrology, numerology, tarot, and Feng Shui, begin with a fundamental belief in geometry. Architects and designers must

Table 1: Geometry in various fields [3].

\begin{tabular}{|c|c|}
\hline Fields & Explanation \\
\hline Geometry in Your Bodyspin & $\begin{array}{l}\text { When studied under the microscope, living cells reveal a highly ordered system of shapes and patterns. From the shape } \\
\text { of your DNA to the cornea of your eye, every part of your body follows the same predictable patterns. }\end{array}$ \\
\hline & $\begin{array}{c}\text { The jigsaw puzzle of life is made up of recurring shapes and numbers. Leaves, flowers, seeds, and other living things } \\
\text { share the same spiral shapes. }\end{array}$ \\
\hline Geometry in Your Garden & $\begin{array}{c}\text { Pine cones and pineapples, in particular, are composed of mathematical spirals. Honeybees and other insects live } \\
\text { structured lives that mimic these patterns. When we create a floral arrangement or walk through a labyrinth, we } \\
\text { celebrate nature's innate forms }\end{array}$ \\
\hline $\begin{array}{l}\text { Geometry in } \\
\text { Stones }\end{array}$ & $\begin{array}{l}\text { Nature's archetypes are reflected in the crystalline forms of gems and stones. Amazingly, the patterns found in your } \\
\text { diamond engagement ring may resemble the formation of snowflakes and the shape of your own cells. The practice of } \\
\text { stacking stones is a primitive, spiritual activity }\end{array}$ \\
\hline $\begin{array}{l}\text { Geometry in the } \\
\text { Sea }\end{array}$ & $\begin{array}{l}\text { Similar shapes and numbers are found beneath the sea, from the swirl of a nautilus shell to the movement of the tides. } \\
\text { Surface waves themselves are patterned, like waves that pulse through the air. }\end{array}$ \\
\hline Geometry in the & Nature's patterns are echoed in the movement of planets and stars and the cycles of the moon. \\
\hline Heavens & Perhaps this is why astrology lies at the heart of so many spiritual beliefs \\
\hline $\begin{array}{l}\text { Geometry in } \\
\text { Music }\end{array}$ & $\begin{array}{l}\text { The vibrations we call sound follow sacred, archetypal patterns. For this reason, you may find that certain sound } \\
\text { sequence can stimulate the intellect, inspire creativity, and evoke a deep sense of joy. }\end{array}$ \\
\hline Geometry in Theology & $\begin{array}{l}\text { Stonehenge, megalithic tombs, and other ancient sites stretch across the globe, along underground electromagnetic } \\
\text { tracks, or ley lines. The energy grid formed by these lines suggests sacred shapes and ratios. }\end{array}$ \\
\hline Geometry in Theology & $\begin{array}{l}\text { Best-selling author Dan Brown has made a lot of money by using the concepts of sacred geometry to weave a spell- } \\
\text { binding tale about conspiracy and early Christianity. Brown's books are pure fiction and have been hotly criticized. But, } \\
\text { even when we dismiss The Da Vinci Code as a tall tale, we can't dismiss the importance of numbers and symbols in } \\
\text { religious faith. Concepts of sacred geometry are expressed in the beliefs of Christians, Jews, Hindus, Muslims, and other } \\
\text { formal religions. }\end{array}$ \\
\hline
\end{tabular}

\section{Geometry in your bodyspin}

When studied under the microscope, living cells reveal a highly ordered system of shapes and patterns. From the shape of your DNA to the cornea of your eye, every part of your body follows the same predictable patterns.

\section{Geometry in your garden}

The jigsaw puzzle of life is made up of recurring shapes and numbers. Leaves, flowers, seeds, and other living things share the same spiral shapes.

Pine cones and pineapples, in particular, are composed of mathematical spirals. Honeybees and other insects live structured lives that mimic these patterns. When we create a floral arrangement or walk through a labyrinth, we celebrate nature's innate forms

\section{Geometry in stones}

Nature's archetypes are reflected in the crystalline forms of gems and stones. Amazingly, the patterns found in your diamond engagement ring may resemble the formation of snowflakes and the shape of your own cells. The practice of stacking stones is a primitive, spiritual activity

\section{Geometry in the sea}

Similar shapes and numbers are found beneath the sea, from the swirl of a nautilus shell to the movement of the tides. Surface draw upon concepts of geometric qualities when they choose particular forms to create pleasing, soul-satisfying spaces [3]. In the following, the paper tried to reflect the ways some numbers and patterns appear again and again in every part of your life to make a sense of harmony in the observe (Table 1). waves themselves are patterned, like waves that pulse through the air.

\section{Geometry in the heavens}

Nature's patterns are echoed in the movement of planets and stars and the cycles of the moon.

Perhaps this is why astrology lies at the heart of so many spiritual beliefs

\section{Geometry in music}

The vibrations we call sound follow sacred, archetypal patterns. For this reason, you may find that certain sound sequence can stimulate the intellect, inspire creativity, and evoke a deep sense of joy.

\section{Geometry in theology}

Stonehenge, megalithic tombs, and other ancient sites stretch across the globe, along underground electromagnetic tracks, or ley lines. The energy grid formed by these lines suggests sacred shapes and ratios.

\section{Geometry in theology}

Best-selling author Dan Brown has made a lot of money by using the concepts of sacred geometry to weave a spell-binding tale about conspiracy and early Christianity. Brown's books are pure 
fiction and have been hotly criticized. But, even when we dismiss The Da Vinci Code as a tall tale, we can't dismiss the importance of numbers and symbols in religious faith. Concepts of sacred geometry are expressed in the beliefs of Christians, Jews, Hindus, Muslims, and other formal religions.

\section{Geometry and Architecture}

Architecture begins with geometry. Since earliest times, architects have relied on mathematical principles. The Greek mathematician Euclid of Alexandria is considered the first person to write down all the rules related to geometry, and that was way back in 300 BC. Then in about 20 BC the ancient Roman architect Marcus Vitruvius wrote down some rules about architecture in his famous De Architecture, or Ten Books on Architecture.

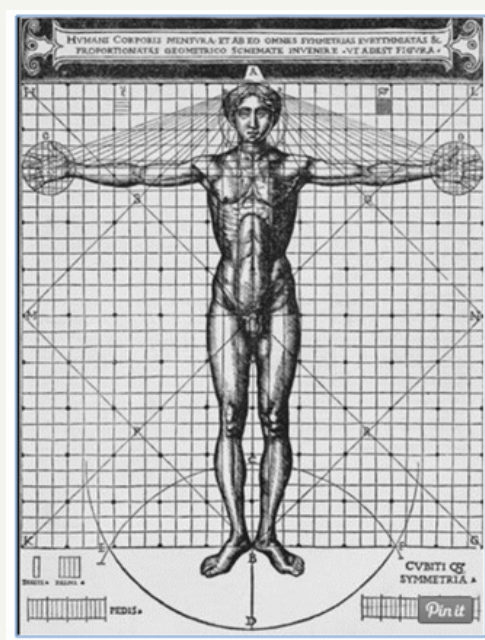

Figure 1: Cesare cesariano.

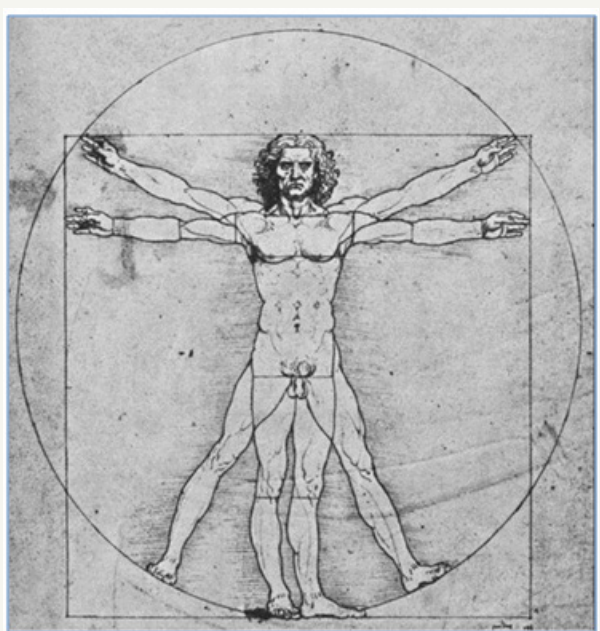

Figure 2: Vitruvian man drawing by Leonardo Da Vinci.

It wasn't until centuries later, during the Renaissance, that interest in Vitruvius was reborn. Cesare Cesariano is said to have been the first architect to translate Vitruvius' work into Italian in about 1520 (Figure 1). Decades earlier, however, the Italian Renaissance Man Leonardo Da Vinci (1452-1519) sketched out the "Vitruvian Man" in his notebook (Figure 2), the iconic image imprinted onto our consciousness even today (Figure 3).

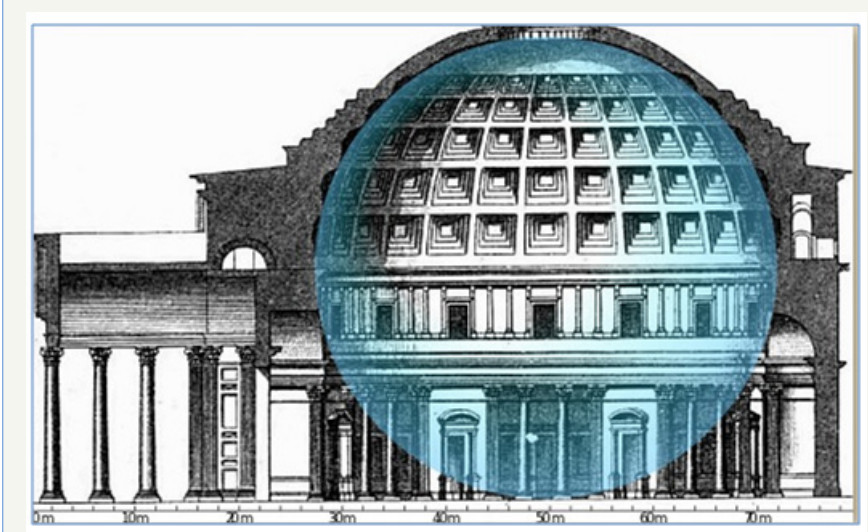

Figure 3: Pantheon, the geometric wonder: A Sphere within a Cylinder.

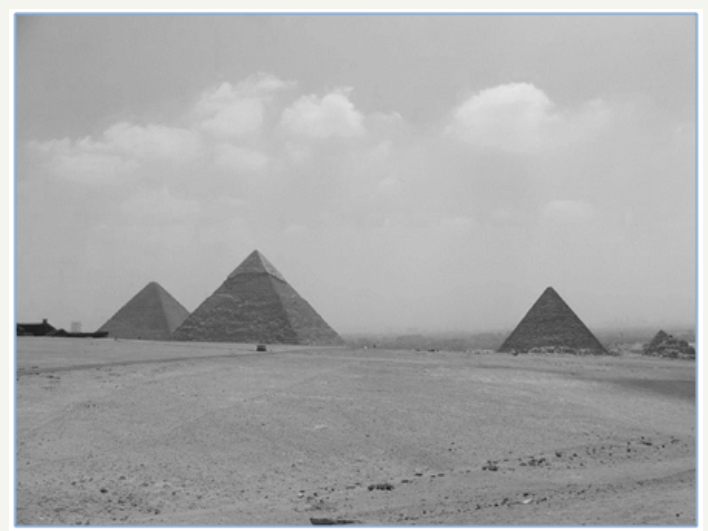

Figure 4: Pyramids at giza plateau.

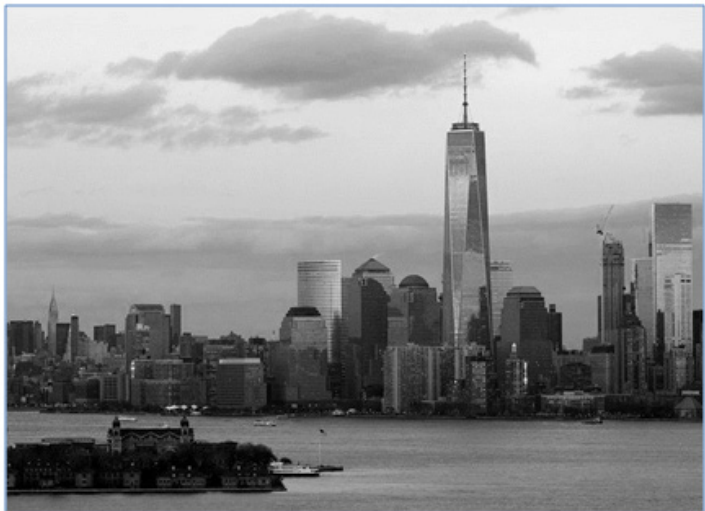

Figure 5: World trade center.

From the pyramids in Egypt (Figure 4) to the new World Trade Center tower (Figure 5) in New York City, great architecture uses the same essential building blocks as your body and all living things. Moreover, the principles of geometry are not confined to great temples and monuments. Geometry shapes all buildings, no matter how humble. Believers say that when we recognize geometric principles and build upon them, we create dwellings that comfort and inspire. Perhaps this is the idea behind the architect's conscious use of divine proportion, like Le Corbusier did for the United Nations building [3]. 


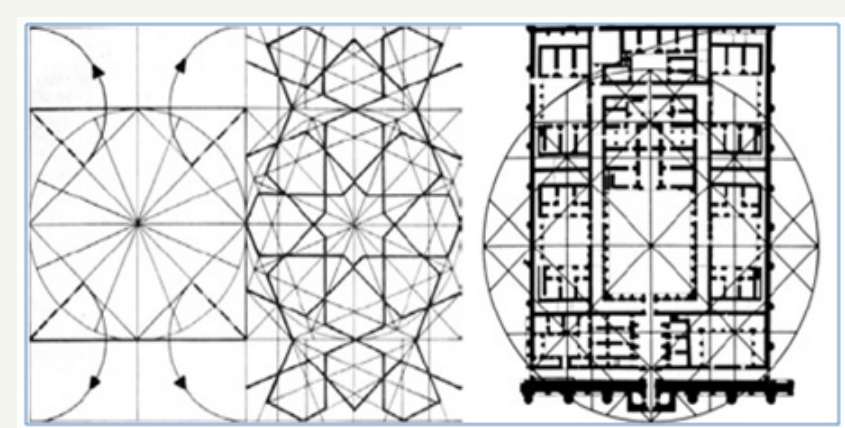

Figure 6: Proportions in iranian architectures and ornamentations.

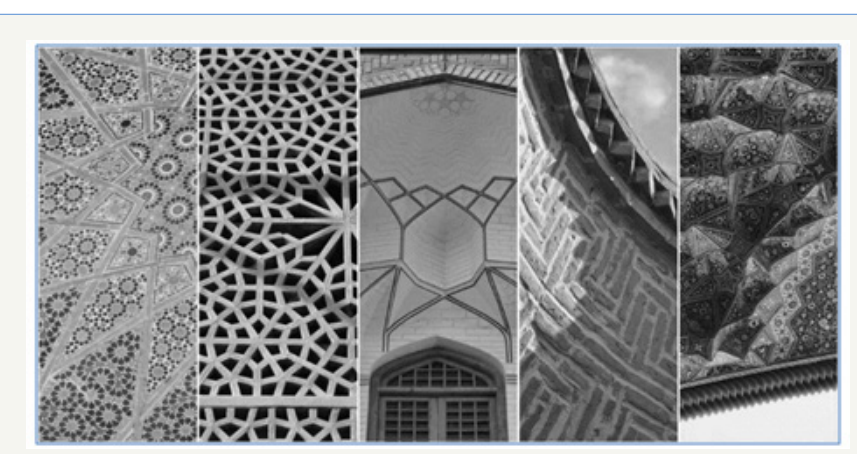

Figure 7: Iranian ornamentation.

\section{Geometry in Iranian Architecture}

It has often been recognized by scholars that geometry plays a significant role in the traditional architecture of Iran [4]. The uses of these geometrical aspects, proportions and measurement have helped architects to develop a set of modular design concept [5]. According to the 10th century philosopher, Abu Nasr al- Farabi, the fundamental of architecture were derived from mathematical science. Furthermore, the basic science of architecture was the knowledge of hiyal. This term is difficult to translate without making any reference to Farabi's discussion of the sciences. Literally, hiyal means "skill, art, cunning", concerning the ingenuity and artistic manipulation of geometric forms [6]. Thus, geometry was the foundation of an architect's training over the past centuries.

\section{History of Employing Geometry (Table 2)}

Table 2: Classification of different periods in Iran.

\begin{tabular}{|c|c|}
\hline General classification & Different dynasties \\
\hline \multirow{4}{*}{ Before Islam } & Before Achaemenid Empire \\
\cline { 2 - 2 } & \\
\cline { 2 - 2 } & Achaemenid Empire \\
\cline { 2 - 2 } & Parthian Empire \\
\hline \multirow{4}{*}{ After Islam } & Sasanian Empire \\
\hline \multirow{4}{*}{} & Sefore Ghaznavid dynasty \\
\cline { 2 - 2 } & Timurid to Ilkhanate Dynasty \\
\cline { 2 - 2 } & Safavid to Qajar Dynasty \\
\cline { 2 - 2 } & Qajar to Contemporary \\
\hline
\end{tabular}

\section{Before achaemenid empire}

Evidence of architecture and urban development in this era indicates that using geometry was an effective factor in urban design and structures. According to Herodotus, Ecbatana city (contemporary Hamedān or Hamedān), capital city of Medians, had completely circular form and the city was surrounded by seven concentric walls? Moreover, these walls had various balanced pathways and structures [7]. In This period, Iranian architecture used symbolic geometry, pure forms such as the circle and square; also, plans were based on symmetrical like rectangular courtyards and hall.

\section{Achaemenid empire}

Achaemenian people were the greatest architects and geometers during Iranian History. Here is Shahkarami's note about Persepolis: experts' investigations on its column structures and their conical forms indicate that: Achaemenian were using number $\pi 2500$ years before mathematics scientists. They were completely familiar with pure mathematics and engineering (Figure 8). They identified the secret of number $\pi$ to build conical masses. They decorate their monuments with simple and frequent repetition of nature or abstract motifs, which were based on axial symmetry. In addition, in Pasargadae complex and royal garden, the geometrical network has been used to design. So it can be concluded that geometry was an influential way to design from micro scales e.g. decorations to macro scales, urban designing and royal complexes [8].

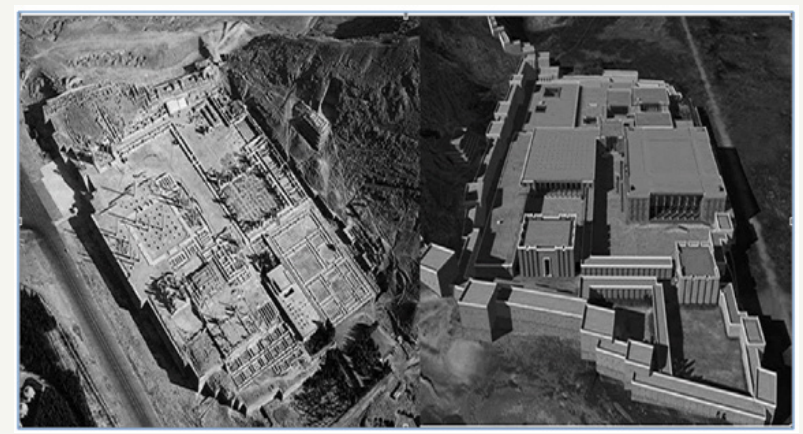

Figure 8: Geometric order and proportion in design Persepolis (Takht-e Jamshid or Pārseh), Shiraz, Fars, ceremonial capital of the achaemenid empire of Iran (ca. 550-330 BC) [8]

\section{Parthian empire}

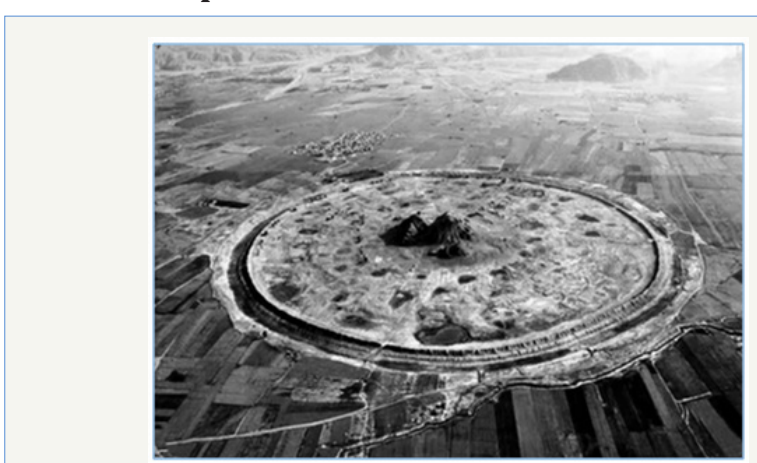

Figure 9: The use of euclidean geometry in the Parthian empire urbanism, ancient round city of Darabgerd, Iran [9]. 
Part tribes were skilled in using advanced techniques of arch and dome with local materials. This skill requires applying strong geometry. In this empire, art and motifs became more geometric and structures became more complicated due to influences of Greek art. For example, the architectural decorations in Nisa have been usually Greek. There were Ionic and Corinthian capitals proportion with acanthus leaves. Nisa's battlements and fortifications, however, had their origin Iranian rules and shape. Moreover, by urban development during Sassanid and Parthian era, the tradition of making circular cities continued in some city such as Darabgerd (Figure 9) [9], Goor (Figure 10) and Khoreh Ardeshir. This fact indicates the usage of geometry in large scales in that time [8].

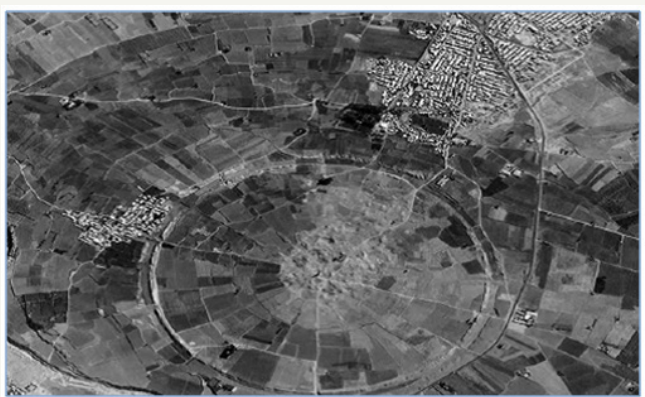

Figure 10: The use of euclidean geometry in the sasanian empire urbanism, ancient city of goor, firuzabad, fars, Iran [8]

\section{Sasanian empire}

In Sassanid dynasty, the use of employing geometry changed from latent state to obvious structures, from frequent and repetition rhythms to elaborate ones. In addition, various motifs and utilizing central symmetry provided a suitable bed for great changes in Islamic Architecture. During this era, dome has been established on square base with specific techniques which convert square to octagon ( $\sqrt{2}$ ratios), Hexagon, and continue this way until arriving highly close to circle. Moreover, central porch of Kasra palace follows $\sqrt{3}$ ratios (has a saloon with a length of $60.34 \mathrm{~m}$ and width of $30.25 \mathrm{~m}$ ) [8].

\section{Before ghaznavid dynasty}

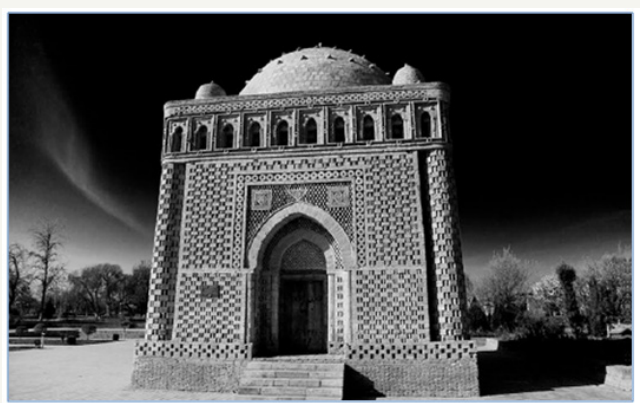

Figure 11: The geometric patterns and construction of their intersections indicate a knowledge of applied geometry, The Samanid mausoleum, Bukhara, Uzbekistan [8].

Since arrival of islam until the ghaznavid dynasty: In early Islam's era, with the gradual development in mathematics, the art of architecture developed too. Top kapı Scroll (valuable source of information, consisting of 114 patterns that may have been used both indirectly and directly by architects to create the tiling patterns in many mosques around the world) could be a good example to show this development. The relationship between applied and theoretical geometry, provide a better context to use theoretical knowledge, mathematics and geometry in applied fields of architecture. On the other hand, geometry has stepped into the decoration of monuments, especially in brick bonding [10] (Figure 11).

\section{Seljuk to ilkhanate dynasty}

On the rise of Seljuk dynasty paying attention to the sciences, especially applied sciences boomed drastically. The evolution and development of Elm Al-Hiyal (Science of Contrivances) especially geometry and architecture occurred in this dynasty. The practical geometry position was one the pivotal issues in training craftsmen and architectures. One of the main features of this dynasty is more employment of geometry in architectural design especially in knot or girih.

In this dynasty, geometry was used as a magnificent tool to balance and generate suitable patterns for monument construction with maximum speed and minimum error. In fact, the modular systems enable architects to build several monuments in different parts of a country simultaneously, without fearing of making mistakes, even in smallest components [8,11] (Figure 12).

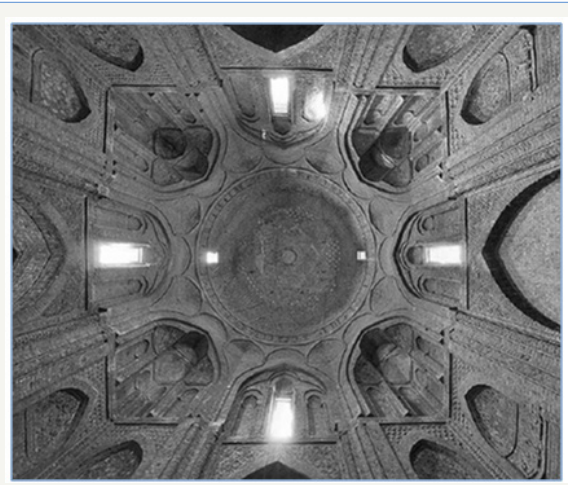

Figure 12: Beautiful brick dome in harmony with geometric proportions, Taj-ol-molk dome, jamé Mosque of isfahan, Isfahan, Iran (1088-1089) [10].

\section{Timurid to safavid dynasty}

Ibn Khaldūn in 14th AD century points to the importance of recognizing geometry in architecture in his famous introduction of describing masonry artifacts. He believed the knowledge of geometry and accurate calculations make craftsmen successful to establish huge monuments. 15th century and Timurid dynasty is the most brilliant historical dynasties of Iranian art and architecture. One of the main features of this dynasty is more employment of geometry in architectural designs, which are substantiated in plans, brickwork in decorations, special geometrical motifs that called muqarn as and diaphoretic tiling (Figure 13) [8]. 


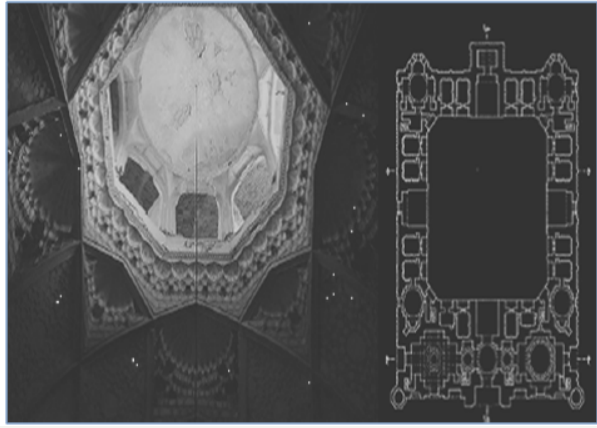

Figure 13: Kharghard madrasa with brick geometrical schemes, Ghiyathiyeh kharghard School, Khaf, Iran [8].

\section{Safavid to qajar dynasty}

In the early 16th century, mathematics and geometry found a particular palace in the architectural field, especially in their capital city "Isfahan". Following Eric Schroeder in "The Great Mosque of Isfahan", using Pentagon and pentagram star on the outer surface of the dome requires scientific skills, domination and proficiency on geometry science. By this skill, the architect was able to convert direct lines to deviant ones, so this fact confirms the strong relation between architecture and geometry. Besides, it could be used as the decorative geometrical shapes to create beautiful motifs [8] (Figure 14).
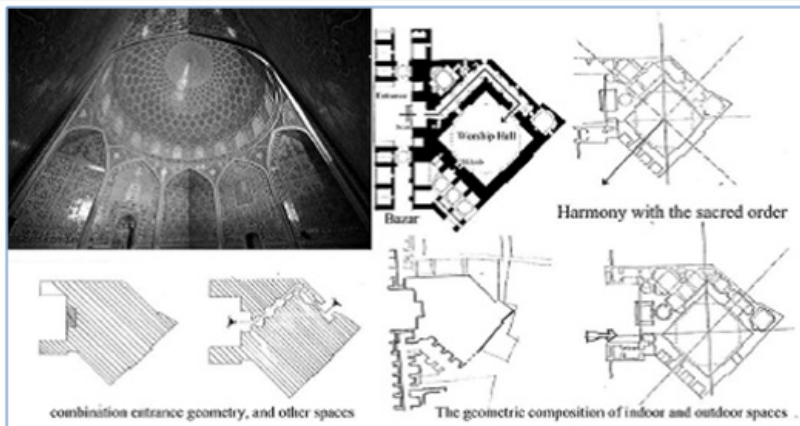

Figure 14: Geometric analysis of sheikh lotfollah mosque, architect mohammad reza isfahani, Isfahan, Iran [8].

\section{Qajar dynasty to contemporary era}

In Qajar dynasty mathematic and geometrical books were translated, corrected and reviewed by several famous mathematicians. Mathematic books authored in Dar Ul-Fonun (the pivotal Iranian educational institution in the nineteenth century) presented some issues according to western and theoretical methods. In this era, mathematics moved away from practical geometry, and tended toward pure and proving issues. The influence of geometry could be seen in decorative tile such as glazed brick or Muqarnas vaults (Figure 15).

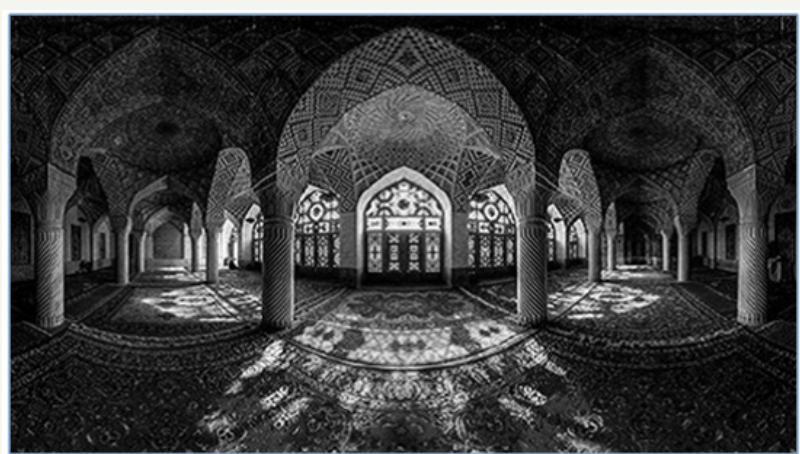

Figure 15: The Nasīr al-Mulk mosque in shiraz, Iran [8].

\section{Results}

i. Comprehensive studies of the relationship between architecture, mathematics and geometry indicated that there has been a close relation between these two fields.

ii. With changes occurred in mathematics, developments in architecture can be seen too.

iii. Although during some periods, this connection became pale, architects never neglect using geometry in their designing. For example, in some eras due to various reasons like social and political circumstances, people's different attitude toward prominent sciences, this relation became weaker but it was never vanished.

iv. During some dynasties, unprecedented progresses in mathematics, compiling books and mathematical achievements such as rulers' support of mathematicians strengthened the architecture and geometry association (Figure 16).

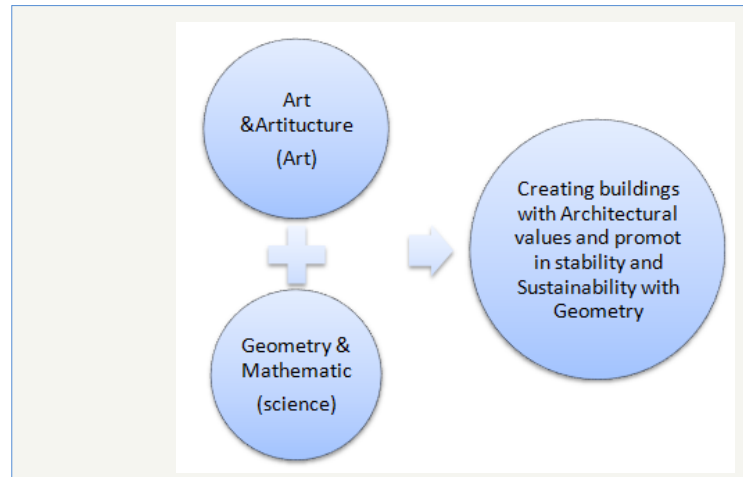

Figure 16: The relationship of mathematics and geometry with art and architecture (Author).

\section{Example of employment Geometry to rebuild lost Part}

Table 3: Samples of reconstruction based on geometry.

\begin{tabular}{|c|c|c|}
\hline Sample & Picture & Explanation \\
\hline $\begin{array}{c}\text { Palladio's Basilica } \\
\text { (Vicenza, Italy) }\end{array}$ & $\begin{array}{c}\text { The stonework is being cleaned and repaired } \\
\text { and the famous curving roof is being replaced } \\
\text { based on Geometrical Calculations. }\end{array}$ \\
\hline
\end{tabular}




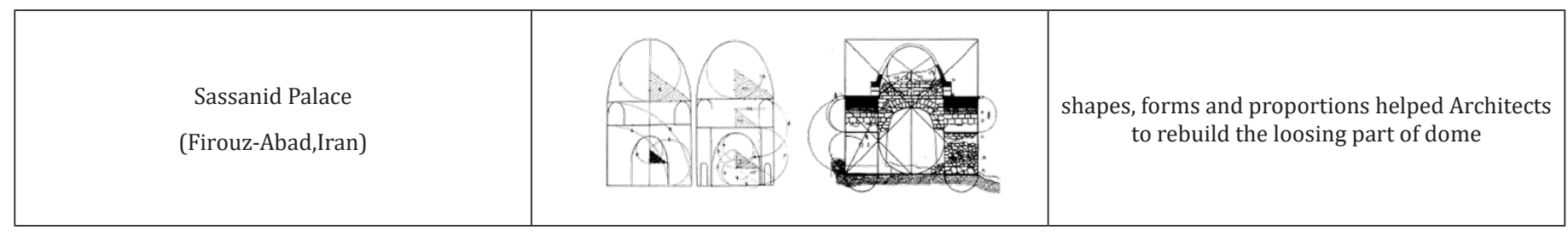

In these two historical building some parts of roof has destroyed over last decades, there were no authentic documents to complete them. However, finding the hidden geometry helped architect to create a successful conservative Project (Table 3).

\section{Conclusion}

The research undertaken on various fields demonstrates geometry and repetitive proportion appears in most parts of your life. Moreover, these studies show by following the nature, traditional architect used natural geometry principles in the historical building. These rules have directly led to make building stable and sustainable beside their beauty and function. Although this paper studied different periods in Iran, these rules could be observed in most areas of the world. In regards to proportions and geometrical rules, it is possible to find a pattern type for rebuilding and reconstruction of lost part of historical buildings. Finally, it is possible to use the methodology of this research for other cases and periods in the world to achieve a more comprehensive understanding of covert masteries in ancient architectures and conservation (Figure 17).

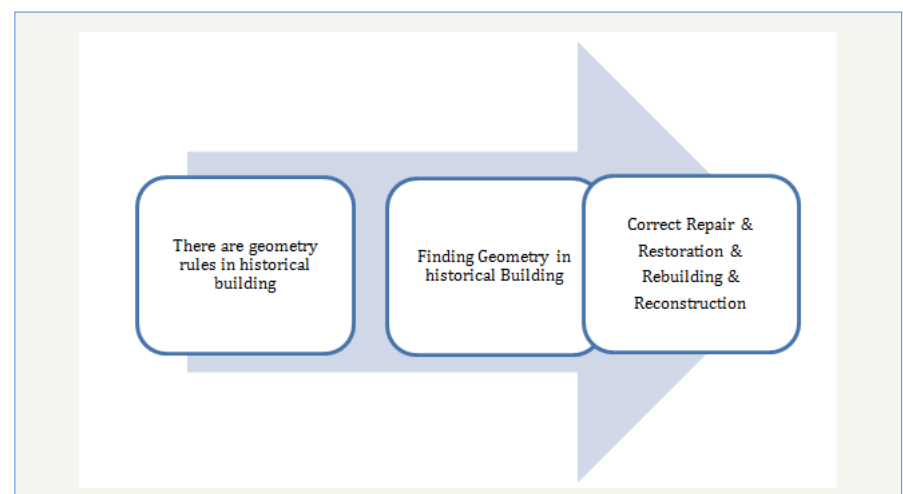

Figure 17: Reconstruction Process based on Geometry.

\section{References}

1. Poudine Halime (2015) Geometry in iranian traditional architecture. Indian Journal of Fundamental and Applied Life Sciences 5(S3): 937-942.

2. Valibeig Nima, Hanieh Mohammadi (2016) Geometry and bonding rules position analysis in the formation of traditional iranian architectural brick facades. Nexus Network Journal 18(2): 467-479.

3. Craven Jackie (2017) Architecture, Geometry, and the Vitruvian Man. ThoughtCo.

4. Ardalan Nader, Laleh Bakhtiar (2000) The Sense of Unity: The Sufi Tradition in Persian Architecture. Kazi Publication Inc., Chicago, USA.

5. Vakili-Ardebili, Ali, Abdel Halim Boussabaine (2006) Quality Concept in Persian Precedent Architecture: A Lesson in Eco-Building Design. The $23^{\text {rd }}$ Conference on Passive and Low Energy Architecture. PELEA, Geneva, Switzerland, Europe.

6. Golombek, Lisa, Donald Newton Wilber (1988) The Timurid Architecture of Iran and Turan. Princeton University Press, New Jersey, USA.

7. Zarei, Mohammad Ebrahim (2000) Introduction to Word Architecture. Fanavaran Publication. Hamedan, Iran.

8. Nejad Ebrahimi Ahad, Morteza Aliabadi (2015) The role of mathematics and geometry in formation of persian architecture. Asian Culture and History 7(1): 220-239.

9. www.Panaromio.com

10. Bemanian, Mohammad Reza, Parham Baghaei, Hanieh Okhovat (2011) Applications of geometry and proportion in architecture. HLH Press, Tehran, Iran.

11. www.panoramio.com 